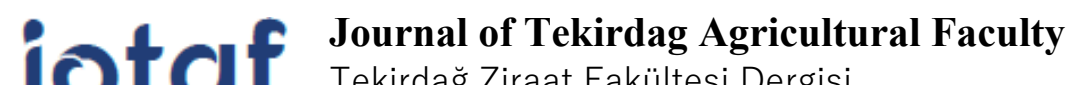 \\ Tekirdağ Ziraat Fakültesi Dergisi
}

\section{Prediction of Photovoltaic Panel Power Outputs Using Time Series and Artificial Neural Network Methods}

Zaman Serileri ve Yapay Sinir Ağı Yöntemleri Kullanılarak Fotovoltaik Panel Güç Çıkışlarının Tahmini

\section{Aylin DUMAN ALTAN ${ }^{1}$, Bahar DIKEN² ${ }^{2}$ Birol KAYIŞOĞLU ${ }^{3}$}

\begin{abstract}
Solar energy is one of the renewable energy sources that has been in high demand in the last decades. With the increasing penetration of photovoltaic (PV) systems in around the world, accurate estimation of the power output of PV systems has become an important issue. Since PV systems directly convert sunlight into electrical energy, PV power output varies depending on environmental conditions. In order to deal with the periodic and nonstationary problems of PV output power, modelling methods are widely use for forecasting. The main purpose of this study is to lead an assessment of forecasting of the PV power outputs in short-time. For this purpose, data are obtained from experimental activities carried out on a real $250 \mathrm{~kW}_{\mathrm{p}}$ PV stystem, which is located in T.C Tekirdağ Namık Kemal University, Süleymanpaşa district of Tekirdağ province. All parametres are measured hourly with three times according to inclination of the panel setups $\left(0^{\circ}, 30^{\circ}, 60^{\circ}\right)$. In this sense, this study differs from the previously studies in literature, as it expands the forecasting model with considering of different panel angle. In the first stage, the significant variables for predicting PV power output are identified based on both correlation analysis and stepwise regression analysis. The findings are shown that solar radiation and angle of inclination of the panel are significant predictors of the generation of PV power. In the second stage, three different model are proposed based on Time Series Analysis (TSA) and Artificial Neural Network (ANN) approaches in order to predict power production of PV system. Furthermore, the accuracies of the models are analyzed in order to better understand the internal errors that occur in energy estimation applications and to evaluate their potential. All models are compared in terms of the correlation coefficient $(\mathrm{R})$, coefficient of determination $\left(\mathrm{R}^{2}\right)$, mean absolute percentage error (MAPE). The results of analyses show that the ANN models have higher accuracy than the TSA model for forecasting PV power.
\end{abstract}

Keywords: Artificial neural network; Back propagation; PV power forecasting; ARIMA, Tekirda $\breve{g}$

\footnotetext{
1*Sorumlu Yazar/Corresponding Author: Aylin DUMAN ALTAN, Tekirdağ Namık Kemal University, ÇORLU Faculty of Engineering 59860 Tekirdağ/TURKEY. E-Mail : aduman@nku.edu.tr (DDrcID:0000-0002-5651-1366

2 Bahar DíKEN, Department of Agricultural Faculty Biosystem Engineering, Tekirdağ Namık Kemal University, 59030 Tekirdağ/TURKEY. E-Mail : bahar233423@hotmail.com, (iD) OrcID: 0000-0002-8087-7595

${ }^{3}$ Birol KAYIŞ̧OĞLU Department of Agricultural Faculty Biosystem Engineering, Tekirdağ Namık Kemal University, 59030 Tekirdağ/TURKEY E-Mail : bkayisoglu@nku.edu.tr , (D)OrcID: 0000-0002-2885-3174

Atıf/Citation: DUMAN ALTAN A., DIKEN B., KAYİSOGLU B. Prediction of Photovoltaic Panel Power Outputs using Time Series and Artificial Neural Network Methods. Tekirdağ Ziraat Fakültesi Dergisi, 18 (3), 457-469.

CBu çalışma Tekirdă̆ Namık Kemal Üniversitesi tarafından Creative Commons Lisansı (https://creativecommons.org/licenses/by-nc/4.0/) kapsamında yayınlanmıştır. Tekirdağ 2021
} 


\section{Öz}

Güneş enerjisi, son yıllarda yüksek talep gören yenilenebilir enerji kaynaklarından biridir. Fotovoltaik (FV) sistemlerin dünya çapında artan yaygınlı̆̆ıyla birlikte, FV sistemleri güç çıkışının doğru tahmini önemli bir konu haline gelmiştir. FV sistemleri doğrudan güneş ışığını elektrik enerjisine dönüştürdüğünden, FV güç çıkışı çevre koşullarına bağlı olarak değişkenlik gösterir. FV çıkış gücünün periyodik olma ve durağan olmama sorunlarının üstesinden gelebilmek amacı ile yapılan tahminlemelerde modelleme yöntemleri yaygın olarak kullanılmaktadır. $\mathrm{Bu}$ çalışmanın temel amacı, kısa süreli FV güç çıkışı tahminlerinin değerlendirilmesinde yol gösterici olmaktır. Bu amaçla toplanan veriler, Tekirdağ ili Süleymanpaşa ilçesine bağlı T.C Tekirdağ Namık Kemal Üniversitesi'nde kurulan bir $250 \mathrm{~kW}_{\mathrm{p}}{ }^{\prime} \mathrm{llk}_{\mathrm{k}} \mathrm{FV}$ sistemi ile gerçekleştirilen deneysel faaliyetlerden elde edilmiştir. Tüm parametreler, saat bazında farklı panel eğim açıları $\left(0^{\circ}, 30^{\circ}, 60^{\circ}\right)$ dikkate alınarak üçer kez ölçülmüş̧ür. Bu anlamda, bu çalışma tahmin modelini farklı panel açılarını da dikkate alarak genişletmesi nedeniyle literatürdeki önceki çalışmalardan farklılık göstermektedir. İlk aşamada, FV güç çıktısını tahmin etmede kullanılacak anlamlı değişkenler hem korelasyon analizi hem de aşamalı regresyon analizi sonuçlarına göre belirlenmiştir. Bulgular, güneş radyasyonunun ve panel eğim açısının, FV gücü üretiminin önemli belirleyicileri olduğunu göstermiştir. İkinci aşamada, FV sisteminin güç üretimini tahmin etmek için Zaman Serisi Analizi (TSA) ve Yapay Sinir Ağı (YSA) yaklaşımlarına dayalı olarak üç farklı model önerilmiştir. Ayrıca, enerji tahmin uygulamalarında ortaya çıkan içsel hataları daha iyi anlamak ve potansiyelini değerlendirmek için modellerin doğrulukları analiz edilmiştir. Tüm modeller korelasyon katsayısı $(\mathrm{R})$, belirleme katsayısı $\left(\mathrm{R}^{2}\right)$, ortalama mutlak yüzde hatası (MAPE) açısından karşılaştırılmıştır. Analiz sonuçları, FV gücünü tahmin etmek için YSA modellerinin TSA modelinden daha yüksek doğruluğa sahip olduğunu göstermektedir.

Anahtar Kelimeler: Yapay sinir ağı, Geri yayılım, FV güç tahmini, ARIMA, Tekirdă̆ 


\section{Introduction}

In parallel to the economy competition of the world, the use and management of energy resources has become an important indicator of development. Renewable energy sources (like solar, wind, etc.) play an important role in electricity generation due to the increasing energy demand linked to fossil fuel depletion and the environmental problems associated with fossil fuel use (Al-Ali, 2016). Solar energy applications are increasing worldwide and development of its technology is significant to meet global energy demand. One of the most notable solar energy applications is photovoltaic (PV) systems which can be convert sun light directly into electric power. The use and management of PV systems require finding the solution to optimization problems on various fields from installation phase to use phase including one or more objectives such as minimum energy costs, maximum energy production, maximum energy efficiency, minimum greenhouse gas emissions etc. On the other hand, using of solar energy as useful energy source have high uncertainty and technical complexity because of the dependence of it on climatic conditions, numerous decision variables and parameters. Solar power production is affected by some environmental and geographical factors like other renewable energy sources. Depending on that, it is not always possible to measure solar power in a particular region require qualified staff and significant economic investments. The estimation of the power output is also vital in terms of factors such as installation of solar panels, guidance of electricity companies, energy management and distribution (Dand1l and Gürgen, 2017). In particular, predictions based on meteorological data constitute a significant reference for determining the installation locations of solar panels. In this way, the cost of panel installation is avoided. Moreover, if after installation, PV output power forecasting is needed to produce estimates for the elimination of risk based on the uncertainty of the amount of production and reduce the cost of energy. Therefore, in recent years several PV power forecasting models have proposed based on different methods and compared performances (Table 1). Though the most applied technique in these forecasting models is ANN, due to their inherent ability to non-linear, dynamic, noisy data and complex system (Ramsami and Oree, 2015), also statistical, physical models are used. In literature, there are many benchmarking studies to determine which approach and under which conditions work best for the proposed situations. In this study, the focus is on TSA and ANN and some studies in the literature related to the prediction of solar power as follows:

In order to boost accuracy of solar power forecasting, in addition to the recommended strategic input selection method and searching for optimal size of network, options of output processing were tested by Netsanet et. al. (2016). It was found that the prediction accuracy can be increased by the use of networks with different learning algorithms and different types of ANN. A back propagation neural network model, which was network structure of 28-20-11, was proposed in order to forecast the power output of a PV system located in Ashland. It was noticed that the corresponding error of MAPE was average $7.16 \%$ for four different forecasting days (Kumar and Kalavathi, 2018). In paper (Abdel-Nasser and Mahmoud, 2019), the performance of the proposed method was compared with three PV forecasting methods: multiple linear regression (MLR), bagged regression trees (BRT), and ANN. As the result, the proposed method with three PV forecasting methods based on MLR, BRT, and ANN methods had best results. The another paper suggested a partial functional linear regression model for predicting the daily solar power and the comparison results based on the real data set collected in Macau, showed that the regularized model improves the forecast accuracy of the MLR and ANN models (Wang et al., 2016). In an experimental study, it was revealed that thermal energy generated by solar collectors can be used efficiently in Tekirdağ (Yüksel Türkboyları, 2018). A PV solar power system, which included a $750 \mathrm{~W}_{\mathrm{p}}$ panel, was constructed in Istanbul Technical University, Istanbul in order to determine time horizon having the highest representative of generated electricity forecasting of small scale system (İzgi et al., 2012). Especially, when stationary conditions were observed, ANN could predict with good performance of to begenerated energy from 3 to 300 minute ahead. In addition, the capabilities of ARIMA and ANN were compared by Ahmed et al. (2014) and the capabilities of SARIMA, SARIMAX and ANN were compared by Vagropoulos et al. (2016) for forecasting of photovoltaic energy production. Kardakos et al. (2013) compared two practical methods for electricity generation forecasting of grid-connected PV plants and detected the ANN models and the modified SARIMA model were superior in terms of the prediction error.

Within the scope of in this study, the literature was examined separately for the determination of the parameters. It is seen that (Table 1) parameters such as irradiance, module temperature, wind speed, air temperature are widely 
used. With some exceptions (Özkişi and Topaloğlu, 2017), in many studies, although the angle of panel was included in the model, measurements were collected by setting up an experimental setup with a constant inclination angle ranging from 0 to 90 . In this case, higher capacity system installations are inevitable, as the sunlight does not come directly, especially in the morning and evening hours (Yüksel Türkboyları and Yüksel, 2021). This problem can be overcome by obtaining maximum benefit from solar energy with the angular mobility of the panel. Therefore, it is even more significant to estimate the PV power by setting the angle of inclination of PV according to the position of sun in the sky. In this study, the measurements was repeated for 3 different angles in each hourly measurement period. Therefore, this paper deals with also the variability of panel angle and this factor also constitutes the originality of the study. Especially, the study is also very significant from the perspective of a model that will be used to predict the energy gains of the moving panel systems that allow the sun rays to fall perpendicular to the panel throughout the period from sunrise to sunset. For this purpose, the models are proposed based on Back Propagation Neural Network (BP-ANN) and ARIMA method and compared the accuracy performance for Tekirdağ location.

Table 1. Input parameters and model used in the literature

\begin{tabular}{|c|c|c|c|}
\hline Article & Year & Inputs & Method \\
\hline Kumar and Kalavathi & 2018 & $\begin{array}{l}\text { Global Horizontal Irradiance, Global Diffused Irradiance, Ambient \& } \\
\text { Surface Temperature, Precipitation, Wind Speed, Air Pressure, Sunshine } \\
\text { Duration, Humidity }\end{array}$ & ANN, ANFIS \\
\hline Hossain et al. & 2017 & Solar Radiation, Wind Speed, Ambient \& Module Temperature & ELM,SVR,ANN \\
\hline Liu et al. & 2017 & Solar Radiation, The Highest, Lowest \& Average Daily Temperature & ANN \\
\hline Özkişi and Topaloğlu & 2017 & Wind Speed, Velocity, Temperature, Humadity, The Angle of the Cells & ANN \\
\hline Huang et al. & 2016 & $\begin{array}{l}\text { Solar Zenith Angle, Solar Azimuth Angle, Solar Irradiance, Module } \\
\text { Temperature }\end{array}$ & $\begin{array}{l}\text { ANN, Algebraic, } \\
\text { Polynomial } \\
\text { Regression }\end{array}$ \\
\hline Ramsami and Oree & 2015 & $\begin{array}{l}\text { Atmospheric Pressure, Humidity, Temperature, Wind Speed, Wind } \\
\text { Direction, Rainfall, Solar Irradiance, Sunshine Duration }\end{array}$ & $\begin{array}{l}\text { Multiple Linear } \\
\text { Regression, FFNN } \\
\text { and GRNN }\end{array}$ \\
\hline İzgi et al. & 2012 & Ambient Temperature, Cell Temperature, Irradiance & ANN \\
\hline
\end{tabular}

The main contributions of paper will be summarized as follows:

* proposed that consider the panel angle changes when constructing the PV power forecasting models for Tekirdağ location.

* predicted of PV power based on ARIMA and BP-ANN methods and the efficiency of the methods are compared.

The rest of this paper is organized as follows. Section 2 presents the problem definition. Section 3 explains the obtained data \& proposed methods. Section 4 presents and discusses the experimental results. The conclusions and some lines of future work are given in Section 5.

\subsection{Problem Definition}

Solar energy production depend on climatic conditions, numerous decision variables and parameters based on environmental and geographical, such as air temperature, wind speed, cloud cover, humidity etc. The intrinsic variability of PV output power creates different problems directly/indirectly for power grid such as power system control and reliability, reserve cost, dispatchable and auxiliary generation, grid integration and power planning (Raza et al., 2016). Therefore, there is need to accurately forecast the PV output over at different conditions depend on location. Since the geographical and environmental conditions of each region are different, the research for the model that makes the most accurate estimation in the region where the PV system is located is inevitable. In this study, experimental setup was established to develop a PV energy production model for Tekirdağ province. Since it was not possible to know which factors affect the PV output power, it was aimed to measure all the factors examined in previous studies on this subject (Table 1). For this purpose, the data were obtained, which was including factors as open circuit voltage, cell temperature, solar irradiance, air temperature, wind speed, short circuit current, solar power and the angle of inclination of the panel. 


\section{Material and Method}

\subsection{Meteorological data}

The solar energy potential atlas of Tekirdağ province, where the experiments carried out, is given in Figure 1. T.C. Tekirdağ Namık Kemal University, where the experimental study conducted, was located in Süleymanpaşa district of Tekirdağ province. Distribution of Süleymanpaşa district annual sunshine duration is shown in Figure 2. Considering the radiation values per unit area of Süleymanpaşa district, May, June, July, August are higher than other months and the global radiation values of Süleymanpaşa district are shown in Figure 3. The average sun radiation in Süleymanpaşa district is $3.68 \mathrm{kWh} \mathrm{m}^{-2}$ per day and the average sunshine time is $7.16 \mathrm{~h}$ per day.



Figure 1. Solar energy potential atlas for Tekirdă̆ (GEPA 2019)

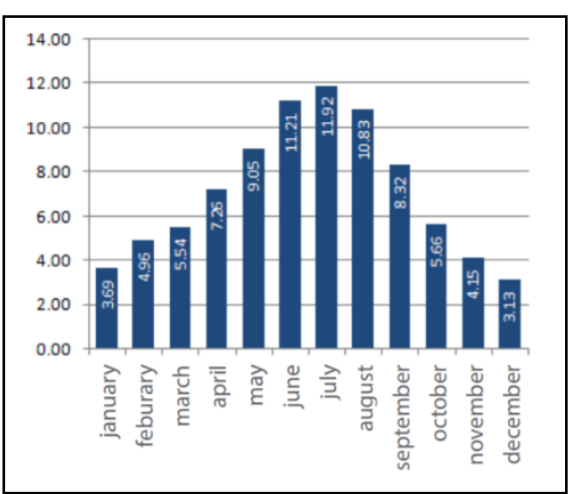

Figure 2. Annual sunshine duration (h) (GEPA 2019)

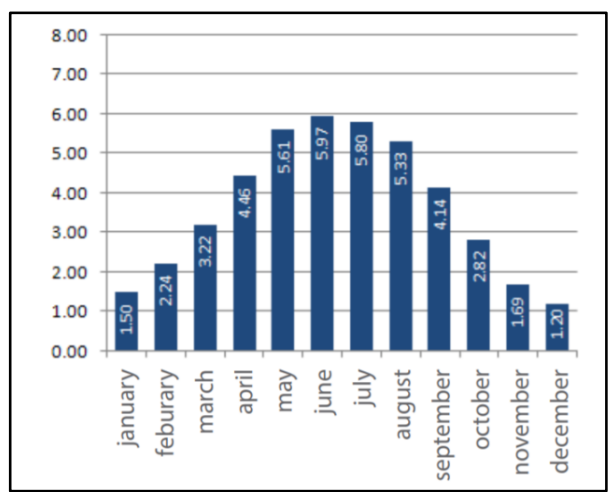

Figure 3. Global radiation value ( $\mathrm{kWh} \mathrm{m}^{-2}$ per day) (GEPA,2019)

\subsection{PV module used in the study and its features}

This experimental study was carried out using CSUN 250-60P branded polycrystalline PV module. The nominal power output of the PV module used in the experimental study has $250 \mathrm{~W}_{\mathrm{p}}$, nominal voltage $29.9 \mathrm{~V}$ and nominal current 8.36 A. Other specific features of the mobile chassis mounted panel are shown in Table 2.

Table 2. Specific features of the PV module

\begin{tabular}{lll}
\hline CSUN 250-60P & Technical properties & Units \\
\hline Maximum Power $\left(\mathrm{P}_{\mathrm{mpp}}\right)$ & 250 & $\mathrm{~W}_{\mathrm{p}}$ \\
Open Circuit Voltage $\left(\mathrm{V}_{\mathrm{oc}}\right)$ & 37.3 & $\mathrm{~V}$ \\
Short Circuit Current $\left(\mathrm{I}_{\mathrm{sc}}\right)$ & 8.81 & $\mathrm{~A}$ \\
Nominal Voltage $\left(\mathrm{V}_{\mathrm{mpp}}\right)$ & 29.9 & $\mathrm{~V}$ \\
Nominal Current $\left(\mathrm{I}_{\mathrm{mpp}}\right)$ & 8.36 & $\mathrm{~A}$ \\
Series Fuse Rating & 20 & $\mathrm{~A}$ \\
Tolerance of $\mathrm{P}_{\mathrm{mpp}}$ & $0 \approx+3$ & $\%$ \\
Weight & 19.1 & $\mathrm{~kg}$ \\
Dimension & $1640 * 990 * 40$ & $\mathrm{~mm}$ \\
Number of cells & 60 & - \\
Effective area & 1.624 & $\mathrm{~m}^{2}$ \\
\hline
\end{tabular}




\subsection{Devices used during measurement}

HT solar IV-400 PV panel analyzer was used to obtain performance data in the PV panel. It has IEC / ENG1010-1 safety certificate as device features and makes measurements in IEC / EN608891 (I-V curve test) standard. The data obtained were transferred to the computer environment with TOPVIEW software. LUTRON AM 4202 electronic digital anemometer was used in the PV arrangement to measure the air flow $\left(\mathrm{ms}^{-1}\right)$ while receiving data from the meter. The connection diagram of the device that receives data and a diagram of the anemometer are shown in Figure 4.
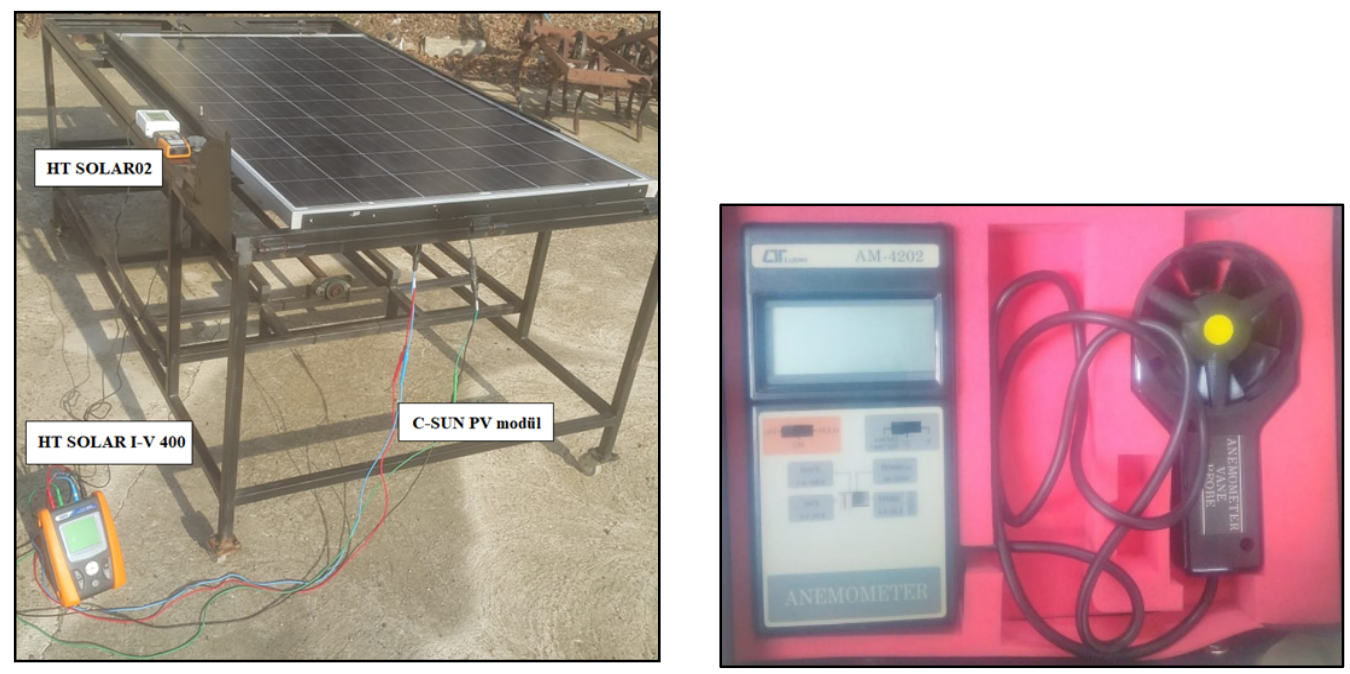

Figure 4. PV module and devices used during measurement

\subsection{Methodology}

The major steps followed in this paper are as shown in Fig. 5.

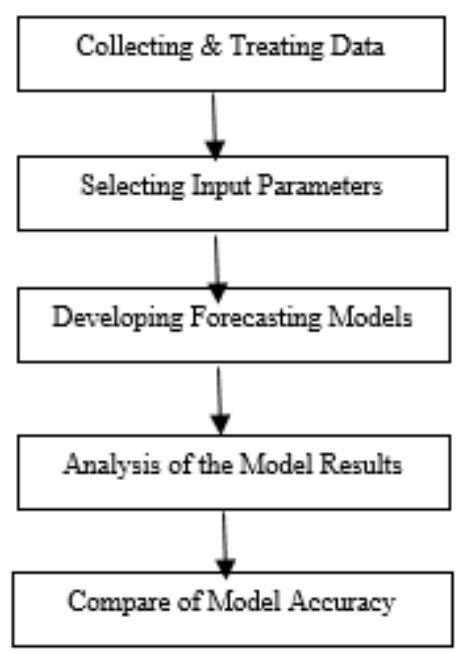

Figure 5. The major steps followed in this paper

The raw data were collected and treated first based on literature. All observations were done between 10.00 pm and 17.00 am during August 2019. The meteorological and electrical data were obtained, which is called Open circuit voltage $\mathrm{V}_{\mathrm{oc}}(\mathrm{V})$, Cell temperature, $\mathrm{T}_{\mathrm{c}}\left({ }^{\circ} \mathrm{C}\right)$, Solar irradiance, $\mathrm{G}\left(\mathrm{W} \mathrm{m}^{-2}\right)$, Air temperature, $\mathrm{T}_{\mathrm{a}}\left({ }^{\circ} \mathrm{C}\right)$, Wind speed, $\mathrm{W}_{\mathrm{s}}\left(\mathrm{m} \mathrm{s}^{-1}\right)$, Short circuit current, $\mathrm{I}_{\mathrm{sc}}(\mathrm{A})$, Solar power, $(\mathrm{W})$, Angle $\left({ }^{\circ}\right)$. All parameters were measured hourly with three times according to inclination of the panel setups $\left(0^{\circ}, 30^{\circ}, 60^{\circ}\right)$. The next step was deciding the model input parameters. Correlation analysis and stepwise regression were used to determine the input parameters.

After the first step of determining the optimal model inputs, the quality of the datasets are also crucial because each dataset had different magnitude. For this reason, the input data is normalized to $[0,1]$ using Eq. (1). 


$$
x_{i k}^{*}=\frac{x_{i k}-x_{\min }}{x_{\max }-x_{\min }}
$$

Where; $x_{\mathrm{ik}}$ is the original data value; $x_{i \mathrm{k}} *$ is the corresponding normalized variable; $y_{\min }$ and $y_{\max }$ is the minimum value and the maximum value in original data sets, respectively. When $x_{\mathrm{ik}}$ is the minimum value in the datasets, $x_{i \mathrm{k}}$ correspond to 0 ; when $x_{i \mathrm{k}}$ is the maximum value in the datasets, $x_{\mathrm{ik}}$ correspond to 1 (Liu et al., 2017).

In this study, both ANN and TSA forecast models were employed to predict the solar power using obtained data set. In this paper, a variation of the classical ARIMA model, which is called the seasonal ARIMA model, was used in order to account for the inherent seasonal effect of the PV power output. The seasonal ARIMA model is generally referred to as SARIMA (p, d, q) x (P, D, Q), where p, d, q and P, D, Q are non-negative integers that refer to the polynomial order of the autoregressive (AR), integrated (I), and moving average (MA) parts of the non-seasonal and seasonal components of the model, respectively (Vagropoulos et al. 2016). The SARIMA model is described mathematically as follows Eq. (2), Eq. (3) and Eq. (4) (Mukaram and Yusof, 2017);

where;

$$
\phi_{p}(B) \Phi_{P}\left(B^{s}\right)(1-B)^{d}\left(1-B^{s}\right)^{D} Y_{t}=\theta_{q}(B) \Theta_{Q}\left(B^{s}\right) e_{t}
$$

$$
\begin{aligned}
& \Phi_{P}\left(B^{s}\right)=1-\Phi_{1} B^{s}-\Phi_{2} B^{2 s}-\cdots-\Phi_{P} B^{s P} \\
& \Theta_{Q}\left(B^{s}\right)=1-\Theta_{1} B^{s}-\Theta_{2} B^{2 s}-\cdots-\Theta_{Q} B^{s Q}
\end{aligned}
$$

and $Y t$ is the observed time series value at time $t$, et is the residual at time $t, B$ is the backshift operator that converts $Y_{t}\left(\right.$ e.g $\left.B Y_{t}=Y_{t-1}\right), S$ is the seasonal period length, $d$ is the number regular difference, $D$ is the number of seasonal difference.

The selection process of the suitable model is basically based on certain information criteria (Akaike Information Criteria and Final Prediction Error), also in addition autocorrelation and partial autocorrelation plots are analyzed.

The method known as ANN was also used to estimate PV power. ANNs are machine learning that have algorithms developed by inspiring the human cell's nerve cell structure. The ANN derives its computing power through its massively paralled distributed structure and its ability to learn and generalize, which means finding reasonable outputs whenever inputs are not encountered during training (learning) (Vaz et al., 2016). It has been proved that a multi-layer (BP) network can achieved due to maximum number of layers can further reduce errors can improve accuracy (Narayanakumar and Raja, 2016). In addition to indicating that the ideal number of layers that can be used in a multi-layer network should be less than 5 (Arifin et al., 2019), it has been determined that the feedforward neural networks with two hidden layers generalise better than those with one (Thomas et al., 2017). The network structure proposed in this study also includes two hidden layers.

In this study, Figure 6 and Figure 7 present the network configuration for Model-2 and Model-3 in MATLAB platform, which are consists of two hidden layer and one output layer.

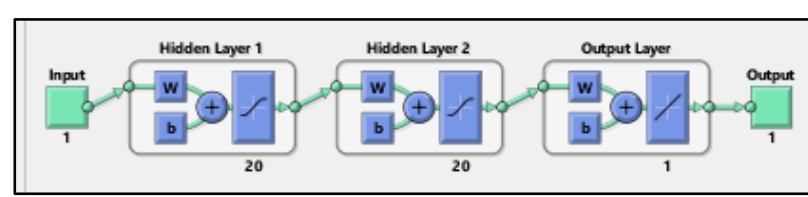

Figure 6. ANN structure of Model-2

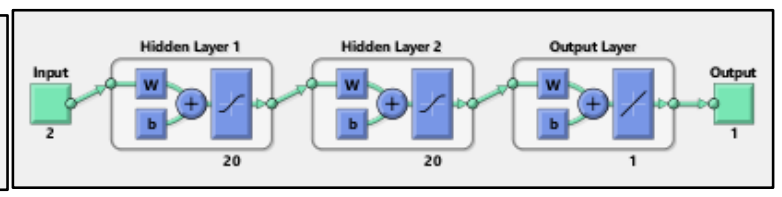

Figure 7. ANN structure of Model-3

For both models, the BFGS-Quasi Newton BP algorithm was used for training and the solar power measured by experimental setup was used as output. The sigmoid function was used as the activation function. In addition, seventy percent of the historical data were used to train the ANN, the remainder $30 \%$ are used for testing and learning rate was determined as 0.8 .

Differently, the obtained data, when the panel inclination was 30 degrees constant, was used in Model-1 (for forecasting based on solar power data) and Model-2 (solar power data used as output and irradiance data used as input). The irradiance and panel angle (when the panel inclination was 0.30 and 60 degrees) data were used as input in Model-3. 
In order to evaluate the obtained results, the mean absolute percentage error (MAPE), R and R2 were used. The MAPE formula is given in the below equation 5 (Liu et al., 2017).

$$
\text { MAPE }=\frac{1}{N} \sum_{i=1}^{N}\left|\frac{P_{i}-P_{i}^{*}}{P_{i}}\right| \times 100 \%
$$

Where; $P_{i}$ is the measured value of power out of the system; $P_{i}^{*}$ is the forecasting value of the power output, $\mathrm{N}$ represents the number of model forecasting samples.

$\mathrm{R}^{2}$ represents the fraction of the sample variation of the $\mathrm{y}$ values that is explained by the independent variables. The largest $\mathrm{R}^{2}$ and the smallest MAPE indicates the best fit of the model. According to Lewis (1982), MAPE values lower than $10 \%$ indicate predictions with high accuracy.

\section{Results and Discussion}

\subsection{Determination of Model Variables}

Electrical data were not used to provide an estimate that does not require measurement with experimental setup. $\mathrm{PV}$ system experimental setup is not required for obtain any parameter data other than the module temperature data. Module temperature variable was excluded from the model, due to the high correlation $(0.768)$ with the radiation parameter as seen in the correlation analysis (Table 3). Based on correlation analyses, irradiance, wind speed, air temperature and angle parameters were selected for model data.

\section{Table 3. Correlations of parametres}

\begin{tabular}{|c|c|c|c|c|c|c|}
\hline & & Angle & Irradiance & Module_Temp & Wind_Speed & Air_Temp \\
\hline \multirow[t]{3}{*}{ Angle } & Pearson Correlation & 1 & $\begin{array}{r}-186^{*} \\
\end{array}$ & -060 & 000 & .000 \\
\hline & Sig. (2-tailed) & & 041 &, 514 & 1,000 & 1,000 \\
\hline & $\mathrm{N}$ & 120 & 120 & 120 & 120 & 120 \\
\hline \multirow[t]{3}{*}{ Irradiance } & Pearson Correlation &,$- 186^{*}$ & 1 &, $768^{*}$ &,- 090 &, $581^{\prime}$ \\
\hline & Sig. (2-tailed) & .041 & &, 000 & .329 &, 000 \\
\hline & $\mathrm{N}$ & 120 & 120 & 120 & 120 & 120 \\
\hline \multirow[t]{3}{*}{ Module_Temp } & Pearson Correlation &,- 060 &, $768^{*}$ & 1 & 012 &, $404^{*}$ \\
\hline & Sig. (2-tailed) &, 514 &, 000 & & ,900 &, 000 \\
\hline & $\mathrm{N}$ & 120 & 120 & 120 & 120 & 120 \\
\hline \multirow[t]{3}{*}{ Wind_Speed } & Pearson Correlation &, 000 & $-0,090$ & 012 & 1 &,$- 233^{\prime \prime}$ \\
\hline & Sig. (2-tailed) & 1,000 & .329 & 900 & & .010 \\
\hline & $\mathrm{N}$ & 120 & 120 & 120 & 120 & 120 \\
\hline \multirow[t]{3}{*}{ Air_temp } & Pearson Correlation & ,000 &, $581^{1 *}$ &, $404^{*}$ &,$- 233^{*}$ & 1 \\
\hline & Sig. (2-tailed) & 1,000 &, 000 & .000 &, 010 & \\
\hline & $\mathrm{N}$ & 120 & 120 & 120 & 120 & 120 \\
\hline
\end{tabular}

The Skewness and Kurtosis were used to judge the normality of data. In literature, though, a normal distribution has both skewness and kurtosis values equal to zero, for psychometric purposes, skewness and kurtosis values between -2 to +2 is acceptable (Muzaffar, 2016). The values of skewness and kurtosis of each model variable fall within the acceptable range of -2 to +2 , Table 4 , shows that the data is fairly normal and the basic assumption of parametric testing is fulfilled.

\section{Table 4. Descriptions based on variables}
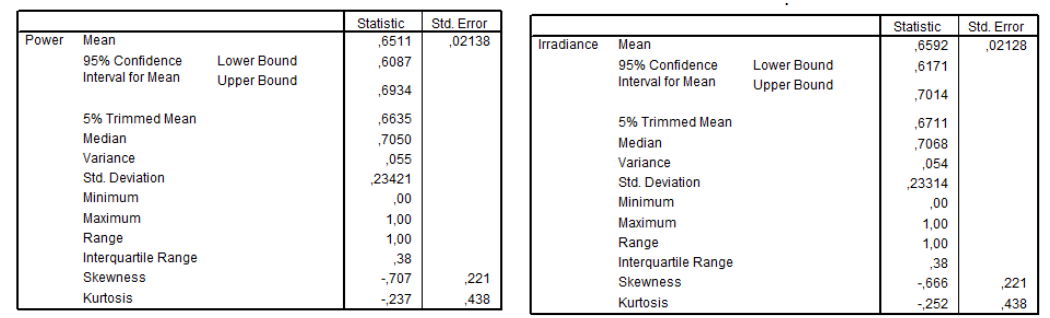

\begin{tabular}{|c|c|c|c|c|}
\hline & & & Statistic & Std. Error \\
\hline & \multicolumn{2}{|l|}{ Mean } & .5000 & \multirow[t]{3}{*}{,03742 } \\
\hline & \multirow{2}{*}{$\begin{array}{l}95 \% \text { Confidence } \\
\text { Interval for Mean }\end{array}$} & \multirow{2}{*}{$\begin{array}{l}\text { Lower Bound } \\
\text { Upper Bound }\end{array}$} & .4259 & \\
\hline & & & 5741 & \\
\hline & \multirow{2}{*}{\multicolumn{2}{|c|}{$\begin{array}{l}\text { 5\% Trimmed Mean } \\
\text { Median }\end{array}$}} & .5000 & \\
\hline & & & .5000 & \\
\hline & \multicolumn{2}{|l|}{ Variance } & . & \\
\hline & \multirow{2}{*}{\multicolumn{2}{|c|}{$\begin{array}{l}\text { Std. Deviation } \\
\text { Minimum }\end{array}$}} & .40996 & \\
\hline & & & .00 & \\
\hline & \multicolumn{2}{|l|}{ Maximum } & 1,00 & \\
\hline & \multicolumn{2}{|l|}{ Range } & 1,00 & \\
\hline & \multicolumn{2}{|l|}{$\begin{array}{l}\text { Interquartile Range } \\
\text { Skewness }\end{array}$} & 1,00 & \\
\hline & $\begin{array}{l}\text { Skewness } \\
\text { Kuntosic }\end{array}$ & & , 000 & .221 \\
\hline & \multicolumn{2}{|l|}{ Kurtosis } & & \\
\hline
\end{tabular}

The stepwise regression results as seen in Table 5. As the result, $\mathrm{F}$ test (P-value $<.000$ for Modell and P-value $<.001$ for Model 2 ) indicates that models are significant for predicting invoice based on a group of independent variables in the models. 
Table 5. SPSS model output 1

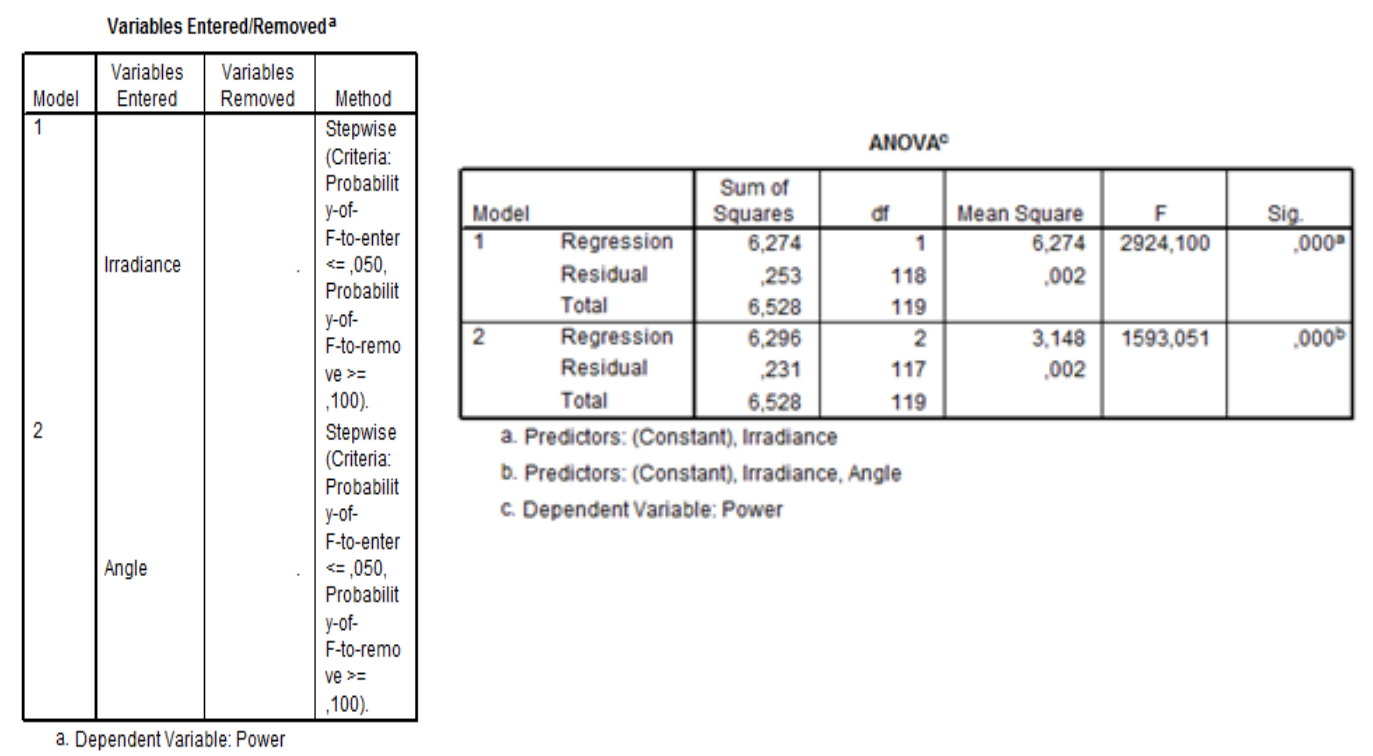

\subsection{Outcome of Proposed Models}

The Model-1 based on SARIMA $(0,1,0) \times(0,1,0)$ model is found to exhibit the best performance (Table 6). The Model-1 forecast capabilities has been confirmed by means of the calculated $\mathrm{R}, \mathrm{R}^{2}$, MAPE, which are respectively equal to $0.603,0.99$ and $13.334 \%$. While $\mathrm{R}^{2}$ and MAPE values have satisfactory performance, $\mathrm{R}$ value is quite low. This result indicates that there may be a $\mathrm{R}^{2}$ height that does not reflect reality due to deviation from the data distribution. This determination is confirmed from the Ljung-Box $(0.94>\mathrm{p})$ value.

Table 6. ARIMA model parameters

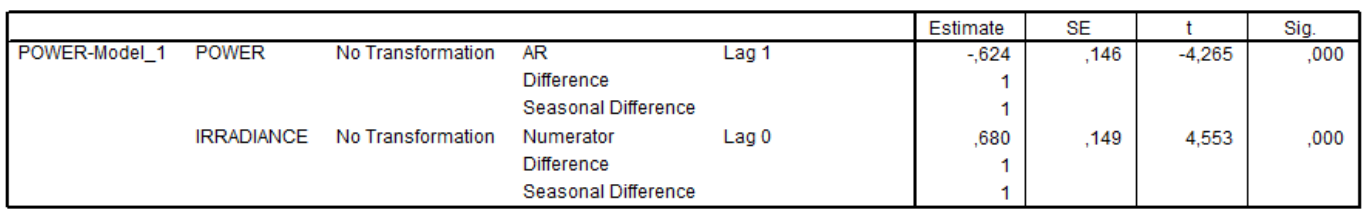

The Model-2 based on BP-ANN forecast capabilities has been confirmed by means of the calculated R, $\mathrm{R}^{2}$, MAPE, which are respectively equal to $0.99626,0.9836$ and $1.95 \%$. According to the results, the model performance in terms of accuracy of the artificial neural networks method is better than the time series analysis. In addition, Figure 8 shows the curve fit in order to predict solar power based on Model-2.



Figure 8. Model-2 curve fit 
Prediction of Photovoltaic Panel Power Outputs Using Time Series and Artificial Neural Network Methods

The output is $99 \%$ of target value and the $\mathrm{R}$ is 0.99721 in the training process. But, in testing process the output is found to be $96 \%$ of the target, with the $\mathrm{R}$ value of 0.99942 . For validation, the output is obtained as $100 \%$ of the target value and the $\mathrm{R}$ value is 0.99298 . Also, the overall $\mathrm{R}$ is obtained as $100 \%$ of the target value and the $\mathrm{R}$ value is 99.626 as described in Figure 8.

Figures 9 and 10 illustrate the performance of the examined forecasting models. As can be seen, the predicted values of power output based on Model-1 have a not good agreement with the measured values, unlike Model-2.

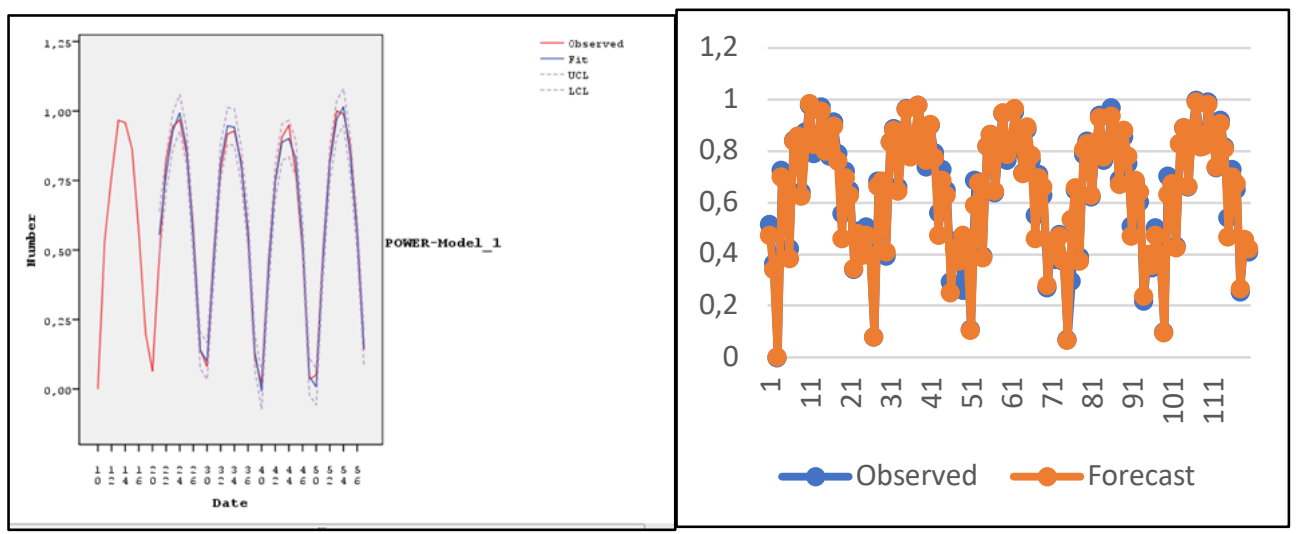

Figure 9. Model-1 Forecasting

Figure 10. Model-2 Forecasting

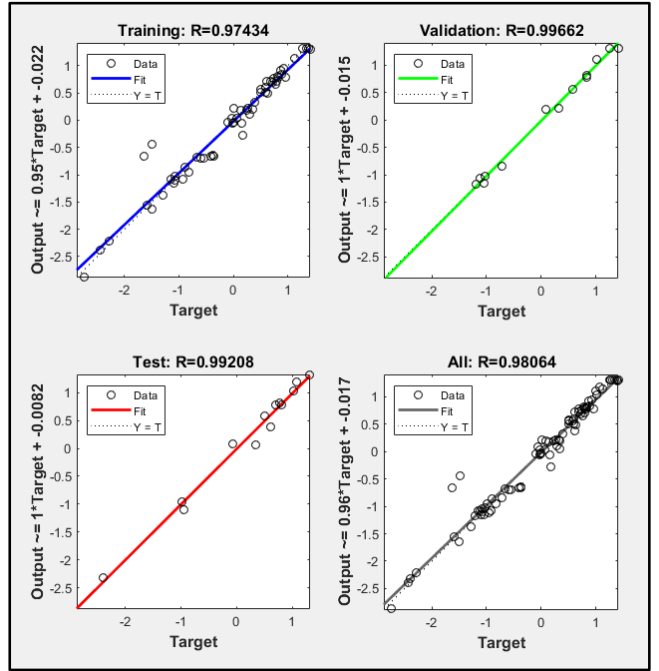

Figure 11. Model-3 curve fit

The Model-3 based on BP-ANN forecast capabilities has been confirmed by means of the calculated R, $\mathrm{R}^{2}$, MAPE, which are respectively equal to $0.98064,0.9779$ and $2.57 \%$. Figure 4.4 shows the curve fit in order to predict solar power based on Model-3. The output is $95 \%$ of target value and the $\mathrm{R}$ is 0.97434 in the training process. But, in testing process the output is found to be $100 \%$ of the target, with the R value of 0.99208 . For validation, the output is obtained as $100 \%$ of the target value and the $\mathrm{R}$ value is 0.99662 . Also, the overall $\mathrm{R}$ is obtained as $96 \%$ of the target value and the $\mathrm{R}$ value is 98.064 as described in Figure 11. The training $\mathrm{R}$ of this model is lower than testing and validation. It means that the data of model have been learning quite well during training. This results similar with Jumaat et al. (2018).

In addition, the calculated performance indexes of models are summarized in Table 7. Based on comparison of indexes, it is clear that the errors are within a reasonable range and the developed BP-ANN model is very suitable for the estimation of PV power output of the system used in this study. It is another important point that the ANN models exhibite superior predictive abilities among the compared time series analysis, as well as are shown a very high predictive power according to the MAPE criterion $(<10 \%)$. 
Nitisanon \& Hoonchareon (2018) and Semenkina et al. (2014) were proposed ANN based models, which used to input as irradiance, the MAPE results were $5.85 \%$ and $4.39 \%$, respectively. In this study, the accuracy results of Model-2 based on MAPE value (=1.95) is also more satisfactory.

Table 7. Performance Indexes of Models

\begin{tabular}{lllll}
\hline Proposed Models & Inputs & $\mathbf{R}$ & $\mathbf{R}^{\mathbf{2}}$ & MAPE \% \\
\hline MODEL1 & Irradiance & 0.603 & 0.3636 & 13.334 \\
MODEL2 & Irradiance & 0.99626 & 0.9836 & 1.95 \\
MODEL3 & Irradiance, Panel Angle & 0.98064 & 0.9779 & 2.57 \\
\hline
\end{tabular}

\section{Conclusion}

This paper presents a forecasting approach using SARIMA and multi-layer BP neural network. One of the most significant results of this study according to stepwise regression analysis is to determine that the panel angle, which is not generally modeled as a variable in studies, is an effective variable on the forecast. Also, it is identified that solar irradiance is a major parameter to change PV power. In this paper, the performance of models was evaluated with the $R, R^{2}$ and MAPE index which shows the accuracy of the models. It is clearly observed from the results that the model performance is better in BP-ANN when compared to the SARIMA. When using the same data set and input-output structure, it is found that more consistent results are obtained with the BP-ANN method. The SARIMA model has been determined to be more sensitive against fluctuations in data. Consequently, a powerful prediction model has been developed specifically for the province of Tekirdağ that can estimate the power production depending on the change in panel angle. In this context, it is predicted that ANN can be successful for energy production estimates of movable panel systems that allow the sun rays to fall perpendicular to the panel. Besides, one of the important contributions of the study is that a highly accurate prediction model has been developed by using input variables that do not require PV system installation for experimental measurements. From this perspective, the proposed model is a helpful tool for users to make more consistent decisions in the preinstallation decision-making process. Nevertheless, due to the irregular manner of meteorological parameters such as solar radiation and wind speed, etc. based on long-term data, there may be a greater variation in all the model accuracy. While the prediction performance of ANN is sufficient for short-times with similar meteorological conditions, the performance of methods based on long-term data should be examined. 


\section{References}

Abdel-Nasser, M., Mahmoud, K. (2019). Accurate photovoltaic power forecasting models using deep LSTM-RNN. Neural Computing \& Applications, 31:2727-2740.

Ahmed, U.M.K., Ampatzis, M., Nguyen, H.P., Kling, L.W. (2014). Application of time-series and artificial neural network models in short term load forecasting for scheduling of storage devices. 49th International Universities Power Engineering Conference (UPEC), ClujNapoca, Romania. 10.1109/UPEC.2014.6934761.

Al-Ali, R.A. (2016). Internet of things role in the renewable energy resources. Energy Procedia, 100:34-38.

Arifin, F., Robbani, H., Annisa, T., Ma'Arof, N.N.M.I. (2019). Variations in the number of layers and the number of neurons in artificial neural networks: Case study of pattern recognition. J. Phys. Conf. Ser. 1413: 0-6.

Dandıl, E., Gürgen, E. (2017). Prediction of photovoltaic panel power output using artificial neural networks learned by heuristic algorithms: A comparative study. International Conference on Computer Science and Engineering (UBMK), Antalya, 397-402.

GEPA (2019). Solar Energy Potential Atlas, http://www.yegm.gov.tr/MyCalculator/, Access Date: 20.05.2020.

Hossain, M., Mekhilef, S., Danesh, M., Olatomiwa, L., Shamshirband, S. (2017). Application of extreme learning machine for short term output power forecasting of three grid-connected PV systems. Journal of Cleaner Production, 167:395-405.

Huang, C., Bensoussan, A., Edesess, M., Tsui, L.K. (2016). Improvement in artificial neural network-based estimation of grid connected photovoltaic power output. Renewable Energy, 97:838-848.

İzgi, E., Öztopal, A., Yerli, B., Kaymak, M.K., Şahin, A.D. (2012). Short-mid-term solar power prediction by using artificial neural networks. Solar Energy Volume 86, Pages 725-723.

Jumaat, A.S., Crocker, F., Wahab, A.H.M., Mohd, H., Radzi, M.H.N., Othman, F.M. (2018). Prediction of Photovoltaic (PV) output using artificial neutral network (ANN) based on ambient factors. Journal of Physics: Conference Series. 1049.

Kardakos, G.E., Alexiadis, C.M., Vagropoulos, I.S., Simoglou, K.C., Biskas, N.P., Bakirtzis, G.A. (2013). Application of time series and artificial neural network models in short-term forecasting of PV power generation. 48th International Universities' Power Engineering Conference (UPEC), Dublin, Ireland, 10.1109/UPEC.2013.6714975

Kumar, R.K., Kalavathib, K.S. (2018). Artificial intelligence based forecast models for predicting solar power generation. Materials Today: Proceedings, 5:796-802.

Lewis, C.D. (1982). Industrial and business forecasting methods: A practical guide to exponential smoothing and curve fitting. London; Boston: Butterworth Scientific.

Liu, L., Liu, D., Sun, Q., Li, H., Wnnersten R. (2017). Forecasting power output of photovoltaic system using a bp network method. Energy Procedia, 142:780-786.

Mukaram, Z.M., Yusof, F. (2017). Solar radiation forecast using hybrid SARIMA and ANN model: A case study at several locations in Peninsular Malaysia. Malaysian Journal of Fundamental and Applied Sciences Special Issue on Some Advances in Industrial and Applied Mathematics, 346-350

Muzaffar, B. (2016). The development and validation of a scale to measure training culture: The TC scale. Journal of Culture, Society and Development, 23: 49-58.

Narayanakumar, S., Raja, K. (2016). A BP Artificial Neural Network Model for Earthquake Magnitude Prediction in Himalayas, India. Circuits and Systems, 7:3456-3468.

Netsanet, S., Zhang, J., Zheng, D., Hui, M. (2016). Input parameters selection and accuracy enhancement techniques in PV forecasting using artificial neural network. 2016 IEEE International Conference on Power and Renewable Energy (ICPRE), Shanghai, 565-569, doi: 10.1109/ICPRE.2016.7871139.

Nitisanon, S., Hoonchareon, N. (2018). Solar power forecast with weather classification using self-organized map. IEEE Power \& Energy Society General Meeting (PESGM), Chicago, IL, USA, 10.1109/PESGM.2017.8274548

Özkişi, H., Topaloğlu, M. (2017). The estimation of the photovoltaic cell productivity with the use of artificial neural network. International Journal of Informatics Technologies, 10(3):247-253.

Ramsami, P., Oree, V. (2015). A hybrid method for forecasting the energy output of photovoltaic systems. Energy Conversion and Management, 95:406-413

Raza, Q. M., Nadarajah, M., Ekanayake, C. (2016) On recent advances in PV output power forecast. Solar Energy, 136:125-144.

Semenkina, M., Akhmedoval, S., Semenkin, E., Ryzhikov, I. (2014) Spacecraft solar arrays degradation forecasting with evolutionary designed ANN-based predictors. ICINCO-Proc. 11th Int. Conf. Informatics Control. Autom. Robot,421-428, 10.5220/0005122004210428.

Thomas, A.J., Petridis, M., Walters, S.D., Gheytassi, S.M., Morgan, R.E. (2017) Two hidden layers are usually better than one. Engineering Applications of Neural Networks, Springer International Publishing, 279-290. https://doi.org/10.1007/978-3-319-65172-9_24. 
Vaz, R.G.A, Elsinga, B., Van Sark, W. Brito, C. M. (2016). An artificial neural network to assess the impact of neighbouring photovoltaic systems in power forecasting in Utrecht, the Netherlands. Renewable Energy, 85:631-641.

Vagropoulos, I.S., Chouliaras, I.G., Kardakos, G.E., Simoglou, K.C., Bakirtzis, G.A. (2016). Comparison of SARIMAX, SARIMA, Modified SARIMA and ANN-based models for short-term PV generation forecasting. IEEE International Energy Conference (ENERGYCON), Leuven, Belgium, 10.1109/ENERGYCON.2016.7514029

Wang, G., Su, Y., Shu, L. (2016). One-day-ahead daily power forecasting of photovoltaic systems based on partial functional linear regression models. Renewable Energy, 96:469-478.

Yüksel Türkboyları, E. (2018). Tekirdağ koşullarında güneş kolektörlerinden elde edilen isı enerjisi ile sera toprağının dezenfekte edilmesi. Tekirdağ Ziraat Fakültesi Dergisi, 15(01):123-128.

Yüksel Türkboyları, E., Yüksel, A.N. (2021). Use of solar panel system in vermicompost (worm manure) production facilities as source of energy. Journal of Tekirdag Agricultural Faculty, 18(1): 91-97. 